\title{
TEACHER'S DISTRIBUTION PATTERN AS DETERMINANTS OF EFFECTIVE TEACHING AND LEARNING IN NIGERIA SECONDARY SCHOOLS
}

\author{
Scott Ekere ${ }^{1}$, Ogunlade J Olurotimi ${ }^{1}$, and Adeleye J Olusola ${ }^{1}$ \\ ${ }^{1}$ Affiliation not available
}

September 29, 2021

\begin{abstract}
The study investigated teacher's demographic factors to ascertain teaching learning issues in Nigeria. As a descriptive survey, teachers and students in senior secondary schools in Ekiti State constituted the study population. The sample comprised of 288 teachers and 1920 students, randomly selected from 32 schools that were stratified, selected and drawn from 16 local government areas in Ekiti State. Four different measuring instruments were used to collect data. The data collected were subjected to statistical analysis using t-test. Findings from the documentary evidence revealed there is uneven distribution of teachers between sex and location, while statistical calculation results revealed that there is a difference between the effectiveness of male and female teachers as well as teachers from both urban and rural locations in the improvement of teaching and learning. The study recommended that government should do more to monitor implementation stages of its education policy with special regard to gender and locations of teachers. Serious and genuine implementation of policy is as important as its formulation. The inspectorate division of the ministry of education should take seriously the distribution of teachers and monitoring of what goes on in our classrooms, especially schools in rural areas where students expect "miracle" passes.
\end{abstract}

\section{Hosted file}

329_PDFsam_0014th Annuak Int'l Conference on Education_Kenya.pdf available at https: //authorea.com/users/429718/articles/539720-teacher-s-distribution-pattern-asdeterminants-of-effective-teaching-and-learning-in-nigeria-secondary-schools 